\title{
ANALISIS PENAMBAHAN BAKTERI Azospirillum sp. TERHADAP KEPADATAN SEL DAN KANDUNGAN LIPID MIKROALGA Chlorella Sp. SERTA PENYISIHAN N TOTAL DI LIMBAH CAIR TAHU
}

\author{
Shinta Elystia ${ }^{1)}$, Mesy Susri Darsi' ${ }^{1)}$, Sri Rezeki Muria ${ }^{2)}$ \\ ${ }^{1)}$ Program Studi Teknik Lingkungan, Universitas Riau, Riau \\ ${ }^{2)}$ Jurusan Teknik Kimia, Universitas Riau, Riau \\ E-mail:shintaelystia@yahoo.com
}

\begin{abstract}
Abstrak
Biomassa mikroalga Chlorella sp. mampu menghasilkan lipid yang dapat dikonversi menjadi biodiesel sebagai energi alternatif bahan bakar fosil disamping perannya dalam pengolahan limbah. Oleh karena itu, teknik budidaya mikroalga tersebut menjadi penting untuk dikembangkan. Salah satunya dengan memanfaatkan bakteri Azospirillum sp. yang bisa meningkatkan pertumbuhan Chlorella sp. dalam pembentukan lipid dan menurunkan kadar pencemar pada limbah cair tahu. Pada penelitian ini dilakukan pengukuran pertumbuhan dan jumlah lipid yang dihasilkan Chlorella sp. serta mengetahui hubungan bakteri Azospirillum sp. dan Chlorella sp. dalam menurunkan kadar penyisihan nitrogen total di limbah cair tahu. Penelitian dilakukan secara batch dengan perlakuan penambahan bakteri dengan 5 level yang berbeda, yaitu 0 (tanpa penambahan bakteri), penambahan bakteri sebanyak 0,25;0,50;0,75 dan 1 (\%v/v). Proses pengolahan dilakukan selama 13 hari dengan penyinaran cahaya matahari dalam fotobioreaktor. Berdasarkan hasil penelitian, kepadatan tertinggi diperoleh dari perlakuan penambahan $1 \%$ bakteri Azospirillum sp. sebesar 9,26 × $10^{6} \mathrm{sel} / \mathrm{ml}$. Perlakuan dengan penambahan 1\% mampu menghasilkan lipid $24,38 \%$ dengan efisiensi penyisihan $N$ total sebesar $66,67 \%$.
\end{abstract}

Kata Kunci: Azospirillum sp., Chlorella sp., Kadar Lipid, Kepadatan Sel, Limbah Cair Tahu, N total

\begin{abstract}
Microalgae biomass Chlorella sp. able to produce lipids that can be converted into biodiesel as an alternative energy for fossil fuels in addition to its role in waste treatment. Therefore, it is important to develop this microalgae cultivation technique. One of them is by using the Azospirillum sp. which can increase the growth of Chlorella sp. in the formation of lipids and reducing pollutant levels in tofu liquid waste. In this study, measurements of the growth and amount of lipids produced by Chlorella sp. and knowing the relationship between Azospirillum sp. and Chlorella sp. in reducing the total nitrogen removal rate in tofu liquid waste. The research was conducted in batches with the addition of bacteria with 5 different levels, that is 0 (without the addition of bacteria), the addition of bacteria as much as 0.25; 0.50; 0.75 and 1 $(\% \mathrm{v} / \mathrm{v})$. The processing is carried out for 13 days by irradiating sunlight in a photobioreactor. Based on the results of the study, the highest density was obtained from the addition of $1 \%$ treatment of Azospirillum sp. amounted to $9.26 \times 10^{6} \mathrm{cells} / \mathrm{ml}$. Treatment with the addition of $1 \%$ was able to produce $24.38 \%$ lipids with a total $N$ removal efficiency of $66.67 \%$.
\end{abstract}

Keywords: Azospirillum sp., Chlorella sp., Lipid Content, Cell Density, Tofu Liquid Waste, N Removal

\section{PENDAHULUAN}

Bahan bakar fosil merupakan jenis sumber daya yang tidak terbarukan atau lama kelamaan akan habis. Selain itu juga berdampak buruk bagi lingkungan karena dapat meningkatkan kadar gas rumah kaca yang menjadi penyebab pemanasan global dan perubahan iklim dunia sehingga mengganggu stabilitas ekologi dan ketahanan pangan (Christenson dan Sims, 2011). 
Biodiesel dari mikroalga memiliki potensi terbesar untuk menggantikan minyak bumi di antara sumber energi terbarukan. Selain efektif dalam menurunkan kadar pencemar, biomassanya dapat dimanfaatkan sebagai produksi lipid untuk dijadikan bahan baku pembuatan biodisel (Hadiyanto dan Azim, 2012). Mikroalga mempunyai kemampuan yang sangat besar untuk dijadikan sebagai sumber energi alternatif seperti biodiesel karena memiliki kandungan lipid yang dapat dijadikan sebagai bahan baku pembuatan biodiesel. Mikroalga dapat memproduksi energi 20 sampai 100 kali lipat dibanding tumbuhan tingkat tinggi lain.

Chlorella sp. merupakan salah satu mikroalga yang berpotensi menghasilkan lipid sebagai bahan dasar untuk memproduksi biodiesel karena kandungan minyaknya yang tinggi. Dapat diketahui, kandungan lipid dari Chlorella sp. berkisar 10\%-48\% dari berat kering (Fihriani, 2015). Akan tetapi nilai kandungan lipid dalam Chlorella sp. tersebut dapat ditingkatkan, dimana saat ini teknik perbanyakan jenis mikroalga menjadi penting dan dikembangkan untuk meningkatkan hasil produksi lipid dari Chlorella sp. Salah satu cara yang mulai dikembangkan yaitu mensimbiosiskan mikroalga dengan bakteri pendukung pertumbuhan tanaman seperti Azospirillum sp. (Yao et al., 2018).

Simbiosis mikroalga dengan bakteri pendukung pertumbuhan tanaman dapat meningkatkan kandungan lipid pada mikroalga serta efisiensi dalam menyisihkan pencemar, terutama limbah cair tahu. Dimana mikroalga menghasilkan oksigen yang tersedia untuk bakteri. Sebagai imbalannya, bakteri memberikan $\mathrm{CO}_{2}$, vitamin $\mathrm{B}$ dan nutrisi anorganik untuk mendukung pertumbuhan lebih lanjut dari mikroalga (Yang et al., 2012). Mikroalga dan bakteri bersinergis dalam mempengaruhi fisiologi dan metabolisme masing-masing, meskipun bakteri sering dianggap sebagai kontaminasi dalam budaya alga. Namun, dalam beberapa tahun terakhir, persepsi telah berubah dan hubungan antara mikroalga-bakteri dianggap menjanjikan bagi perkembangan bioteknologi, karena banyak studi terbaru menunjukkan efek positif dari simbiosis ini dapat meningkatkan biomassa dan produksi biofuel berbasis mikroalga di masa depan.

Salah satu mikroorganisme yang dimanfaatkan dalam pertanian dan disebut sebagai Plant Growth Promoting Bacteria (PGPB) adalah Azospirillum sp. Dibidang pertanian, bakteri ini dimanfaatkan sebagai biofertilizer atau pupuk hayati. Bakteri ini dikenal karena kemampuannya menghasilkan hormon nabati Indol Acetid Acid (IAA) (Spaepen et al., 2007). Fitohormon mengubah metabolisme dan morfologi tanaman seperti bertambahnya 
jumlah rambut akar, akar semakin panjang, dan permukaan akar yang semakin luas menyebabkan penyerapan mineral dan air lebih baik, akibatnya tanaman lebih besar dan lebih sehat (Nursoid, 2008). Menurut Bahsan et al (2008), pada kultivasi mikroalga fitohormon ini dapat meningkatkan pertumbuhan sel yang menyebabkan populasi sel menjadi lebih besar. Selain itu bakteri ini mampu menghasilkan vitamin B12 yang mendukung pertumbuhan mikroalga. Tang et al (2010) mengatakan bahwa dari 332 spesies mikroalga yang diteliti, menunjukkan bahwa 54\% spesies alga membutuhkan vitamin B12. Hal ini menunjukkan bahwa pentingnya vitamin B12 bagi pertumbuhan mikroalga sehingga bakteri ini dapat disimbiosiskan dengan mikroalga karena mampu meningkatkan pertumbuhan mikroalga. Sehingga pada penelitian ini akan dilakukan penambahan bakteri Azospirillum sp., pada kultivasi mikroalga Chlorella sp. sehingga dapat meningkatkan pertumbuhan mikroalga dan meningkatkan kemampuan mikroalga sebagai pengolah limbah untuk menurunkan parameter pencemar disamping manfaatnya sebagai bioenergi.

\section{METODE PENELITIAN}

\subsection{Alat dan Bahan}

Alat-alat yang digunakan dalam penelitian ini adalah fotobioreaktor berukuran $20 \mathrm{~cm}$ x 10 $\mathrm{cm}$ x $30 \mathrm{~cm}$ (Gambar 1), oven, pH meter, kertas saring, corong, gelas ukur $10 \mathrm{ml}$ dan 100 $\mathrm{ml}$, pipet tetes, spatula, desikator, timbangan analitik, hand counter, cover glass, tabung reaksi dan sentrifuge, jarum ose, cawan petri, autoclave, beaker glass, inkubator, penjepit erlenmeyer, corong pisah, mortar, thermometer, aerator dengan debit udara 3 1/menit, mikroskop cahaya dan thomacytometer.

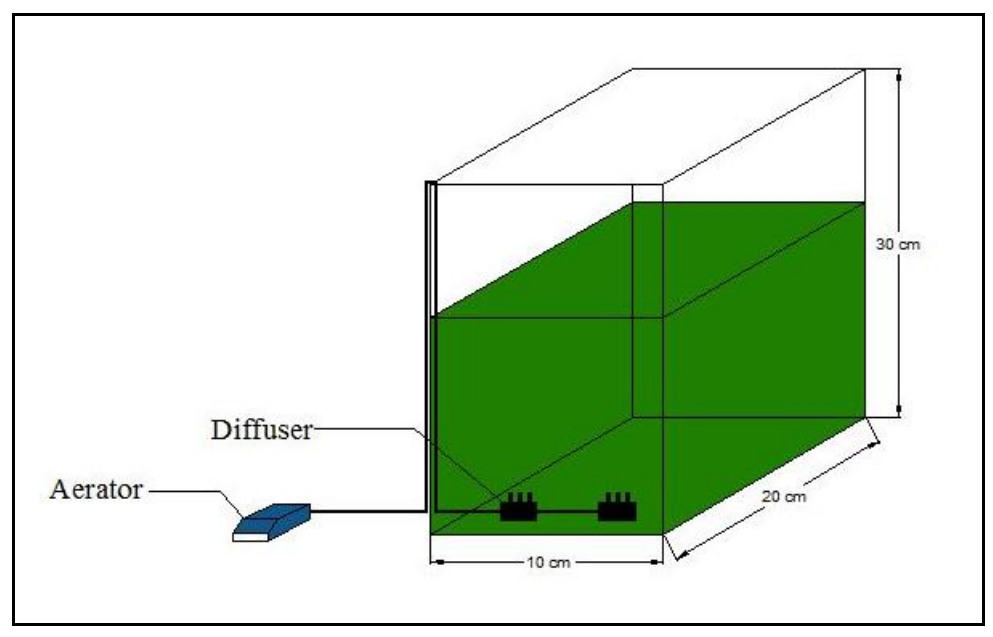

Gambar 1. Desain Fotobioreaktor

Bahan yang digunakan dalam penelitian ini adalah limbah cair tahu yang digunakan berasal 
dari industri tahu rumahan di jalan Garuda Ujung, Kelurahan Tangkerang Tengah, Kecamatan Marpoyan Damai, Pekanbaru. Mikroalga yang digunakan yaitu Chlorella sp. dari Pusat Penelitian Alga Fakultas Perikanan dan Ilmu Kelautan Universitas Riau, medium Dahril Solution (Tabel 1). Bakteri Azospirillium sp. diperoleh dari Indonesian Culture Collection (InaCC), Research Center for Biology, Lembaga Ilmu Pengetahuan Indonesia (LIPI), Bogor yang diremajakan pada medium NA kemudian dibuat kultur stok bakteri cair pada medium NB. Bahan kimia pendukung yang dibutuhkan dalam penelitian ini diantaranya: Alkohol $70 \%, \mathrm{H}_{2} \mathrm{SO}_{4}, \mathrm{NaOH}$, kloroform, methanol dan bahan kimia untuk analisis parameter.

Tabel 1. Komposisi Medium Dahril Solution

\begin{tabular}{cc}
\hline Nama Bahan & Jumlah \\
\hline $\mathrm{KNO}_{3}$ & $100 \mathrm{mg}$ \\
$\mathrm{MgSO}_{4} .7 \mathrm{H}_{2} \mathrm{O}$ & $25 \mathrm{mg}$ \\
$\mathrm{K}_{2} \mathrm{HPO}_{4}$ & $25 \mathrm{mg}$ \\
$\mathrm{NaCl}_{2}$ & $10 \mathrm{mg}$ \\
$\mathrm{CaCl}_{2} .2 \mathrm{H}_{2} \mathrm{O}$ & $1,0 \mathrm{mg}$ \\
Larutan Fe & $0,1 \mathrm{ml}$ \\
Larutan A5 & $0,1 \mathrm{ml}$ \\
Vitamin B12 & $140 \mathrm{u}$ \\
Air Suling & $99,8 \mathrm{ml}$ \\
\hline
\end{tabular}

\subsection{Variabel Penelitian}

\subsubsection{Variabel Tetap}

Variabel tetap dalam penelitian ini yaitu: Konsentrasi suspensi alga dalam fotobioreaktor $25 \%$ (Zulfarina et al, 2013), dimensi fotobioreaktor $20 \mathrm{~cm}$ x $10 \mathrm{~cm}$ x $30 \mathrm{~cm}$, dan volume kerja fotobioreaktor 3 liter.

\subsubsection{Variabel Bebas}

Variabel bebas dalam penelitian ini yaitu: Konsentrasi bakteri Azospirillum sp. dalam fotobioreaktor $(0 \%, 0,25 \%, 0,50 \%, 0,75 \%$ dan $1 \% \mathrm{v} / \mathrm{v}$ (volume bakteri : volume kerja).

\subsection{Prosedur Penelitian}

\subsubsection{Persiapan Peralatan}

Penelitian ini menggunakan fotobioreaktor yang terdiri dari lima buah kolam kaca dengan ukuran yang sama yaitu (P x L x T) $20 \mathrm{~cm}$ x $10 \mathrm{~cm}$ x $30 \mathrm{~cm}$. Reaktor ini termasuk dalam closed fotobioreaktor dimana desain relatif lebih murah dan mudah dibersihkan serta memiliki luas permukaan pencahayaan yang cukup luas Mikroalga dalam reaktor diaerasi 
menggunakan aerator yang berfungsi untuk mengontakkan mikroalga dengan media. Reaktor untuk masing-masing perlakukan penelitian diberikan cahaya dengan sumber cahaya matahari.

\subsubsection{Preparasi Limbah Cair Tahu}

Limbah cair tahu yang digunakan pada penelitian ini berasal dari industri tahu rumahan di jalan Garuda Ujung, Kelurahan Tangkerang Tengah, Kecamatan Marpoyan Damai, Kota Pekanbaru. Limbah cair tahu diambil sebanyak 15 Liter. Kemudian dilakukan uji karakteristik N-Total awal, dimana karakteristik N-Total awal limbah cair tahu didapatkan sebesar $1400 \mathrm{mg} / \mathrm{L}$.

\subsubsection{Seeding dan Aklimatisasi}

Seeding merupakan tahap pembibitan untuk menumbuhkan dan mengembangkan mikroalga yang digunakan dalam proses pengolahan. Proses pembibitan dilakukan selama seminggu menggunakan medium Dahril Solution dengan penyinaran bersumber dari matahari (Dahril, 2012). Selama kultivasi sel dihitung setiap 24 jam menggunakan thomacytometer dan mikroskop. Kultur alga hasil perbanyakan kemudian diaklimatisasi di dalam rumah kaca dengan menggunakan sinar matahari sebagai sumber pencahayaan yang memiliki suhu ruangan dengan nilai rata-rata $30^{\circ} \mathrm{C}$. Aklimatisasi bertujuan untuk membiasakan kondisi alga hasil seeding dengan limbah cair secara bertahap selama dua minggu. Pengamatan dilakukan setiap 1 x 24 jam menggunakan alat thomacytometer dan mikroskop dengan bantuan hand counter untuk menghitung jumlah sel mikroalga sehingga diperoleh kepadatan sel sebesar $10^{6} \mathrm{sel} / \mathrm{ml}$ (Adi et al, 2015). Tahap aklimatisasi dilakukan dengan menggunakan campuran mikroalga dan limbah untuk membantu proses adaptasi mikroalga dengan kondisi baru (Harianja et al, 2019). Tahap pertama dilakukan dengan mencampurkan alga hasil perbanyakan dengan limbah cair tahu dengan perbandingan 50\% : 50\%. Tahap selanjutnya mencampurkan alga dari tahap pertama dan limbah cair tahu dengan rasio sebesar 75\%: $25 \%$ yang nantinya digunakan pada penelitian utama.

\subsubsection{Preparasi Bakteri Azospirillum sp.}

Peremajaan bakteri dilakukan dengan cara menggoreskan koloni bakteri yang diperoleh menggunakan jarum ose steril pada medium NA (Nutrient Agar) dengan metode streak plate. Kemudian diinkubasi selama 24 jam pada suhu $37^{\circ} \mathrm{C}$ (Arwiyanto et al., 1993). Setelah itu dilakukan pembuatan stok kultur bakteri cair. Bakteri hasil peremajaan pada medium NA diinokulasikan satu ose ke dalam $50 \mathrm{~mL}$ media NB (Nutrient Broth) yang 
telah disterilkan dengan autoclave pada suhu $121^{\circ} \mathrm{C}$ selama 15 menit di dalam erlenmeyer dan ditutup dengan kapas. Kultur bakteri dalam Nutrient Broth tersebut diinkubasi pada shaker incubator dengan kecepatan $120 \mathrm{rpm}$ selama 24 jam pada suhu $27-30^{\circ} \mathrm{C}$, selanjutnya kultur dapat dijadikan stock penelitian. Setelah itu biakan tersebut diambil $1 \mathrm{~mL}$ dan dituangkan ke dalam $100 \mathrm{~mL}$ media NB yang telah sterilkan dengan autoclave di dalam erlenmeyer tertutup kemudian dihomogenkan dan diinkubasi pada suhu $37^{\circ} \mathrm{C}$ selama 24 jam kemudian dilakukan perhitungan bakteri menggunakan metode Total Plate Count (TPC) untuk digunakan pada percobaan utama.

\subsubsection{Percobaan Utama}

Limbah cair tahu, suspensi mikroalga dan bakteri Azospirillium sp. dimasukkan ke dalam fotobioreaktor berdasarkan variasi perlakuan, yaitu dengan variasi konsentrasi bakteri Azospirillium sp. dengan kepadatan $10^{8} \mathrm{cfu} / \mathrm{ml}$ dalam fotobioreaktor sebesar 0\%, 0,25\%, $0,50 \%, 0,75 \%$ dan $1 \%$ v/v (volume bakteri : volume kerja). Konsentrasi suspensi alga yang digunakan tetap yaitu sebesar $25 \%$ dari volume kerja $(750 \mathrm{ml})$. Kemudian diberikan sumber cahaya yang berasal dari sinar matahari. Dalam hal ini dilakukan perhitungan jumlah sel awal dari suspensi alga.

\subsubsection{Analisis Data}

\subsubsection{Jumlah Sel Mikroalga}

Perhitungan jumlah sel dilakukan pada setiap hari dimulai dari hari ke-0 hingga hari ke-13 dengan menggunakan alat thomacytometer yang diamati dibawah mikroskop cahaya, kemudian dilakukan perhitungan jumlah sel pada setiap bidang kotak dengan bantuan hand counter. Untuk menghitung jumlah sel Chlorella sp. digunakan rumus:

Keterangan:

$$
\mathrm{N}=\mathrm{n} \times 10^{4}
$$

$$
\begin{array}{ll}
\mathrm{N} & =\text { kelimpahan sel }(\mathrm{sel} / \mathrm{mL}) \\
\mathrm{n} & =\text { jumlah sel dihitung } \\
10^{4} & =\text { volume kotakan thomacytometer }
\end{array}
$$

\subsubsection{Analisis Kadar lipid}

Analisa kadar lipid dilakukan pada hari ganjil kultivasi. Ekstraksi lipid diukur dengan metode Bligh-Dyer. Sebanyak $1 \mathrm{ml}$ sampel dikeringkan hingga nilai beratnya konstan. Setelah itu lipid diekstraksi dengan larutan kloroform-metanol(2:1, v/v) sehingga terpisah menjadi lapisan kloroform dan metanol. Tambahkan metanol dan air untuk menghasilkan 
rasio pelarut akhir kloroform methanol:air sebesar 1:1:0,9. Kemudian lapisan kloroform dicuci menggunakan $20 \mathrm{ml}$ larutan $\mathrm{NaCl} 5 \%$ dan diuapkan hingga kering. Total lipid ditentukan secara gravimetri dengan rumus sebagai berikut (Putri, 2012):

$$
\% \text { Total Lipid }=\frac{\mathrm{Lw}}{\mathrm{Bw}} \times 100
$$

Keterangan:

Lw $\quad=$ Berat lipid (gram)

$\mathrm{Bw}=$ Biomassa $($ gram $)$

\subsubsection{Nitrogen Total}

Parameter N-Total dianalisa diawal, tengah dan akhir kultivasi. Pengukuran N-Total mengacu pada SNI 4146-2013 dengan metode kjeldahl secara titrasi. Prinsip kerjanya yaitu protein dan komponen organik dalam sampel didestruksi menggunakan larutan asam sulfat dan katalis. Kemudian hasil destruksi dinetralkan dengan larutan alkali dan melalui destilasi. Selanjutnya destilat ditampung ke dalam larutan asam borat atau larutan asam klorida. Destilat yang terbentuk kemudian dititrasi menggunakan larutan $\mathrm{HCl}$ atau larutan $\mathrm{NaOH}$. Kadar N-Total dihitung dengan menggunakan rumus:

$$
\% \mathrm{~N}=\mathrm{N} . \mathrm{HCL} \times 14,008 \times 100 \%
$$

Keterangan:

$\mathrm{N}=$ Konsentrasi $\mathrm{N}$-Total $(\mathrm{N})$

$\mathrm{N}=$ Konsentrasi HCL $(\mathrm{N})$

Efisiensi penyisihan parameter N-Total selama proses pengolahan didapatkan melalui perhitungan dengan menggunakan rumus:

Efisiensi (\%) $=\frac{\mathrm{C}_{\text {in }}-\mathrm{C}_{\mathrm{ef}}}{\mathrm{C}_{\mathrm{in}}} \times 100 \%$

Keterangan:

Cin $=$ Konsentrasi influen $(\mathrm{mg} / \mathrm{L})$

Cef $\quad=$ Konsentrasi efluen $(\mathrm{mg} / \mathrm{L})$

\section{HASIL DAN PEMBAHASAN}

\subsection{Kepadatan Sel Mikroalga Chlorella sp.}

Perhitungan kepadatan sel pada hari ke 1 hingga hari ke 4 menunjukkan terjadinya fase lag 
yang ditandai dengan jumlah sel mikroalga Chlorella sp. yang hanya meningkat dalam jumlah yang sedikit. Dimana pada fase ini, sel alga melakukan adaptasi dengan lingkungan barunya di dalam fotobioreaktor. Dalam fase ini, sel-sel Chlorella sp. yang membelah masih sedikit sehingga jumlah sel belum banyak mengalami peningkatan (Hadiyanto dan Hidayat. 2014). Fase eksponensial pada penelitian ini berlangsung sejak hari ke-5. Pada fase ini, terjadi kenaikan pertumbuhan sel maksimum dikarenakan mikroalga melakukan pembelahan sel dengan cepat sehingga densitas sel meningkat. Pada fase ini mikroalga juga mampu menyerap nutrisi pada medium limbah secara optimal (Wijoseno, 2011). Kemampuan Chlorella sp. beradaptasi pada fase lag sebelumnya dipengaruhi oleh adanya proses aklimatisasi mikroalga dalam limbah sehingga lebih aktif dalam memanfaatkan nutrient. Kemudian terjadi fase penurunan pertumbuhan yang ditandai dengan menurunnya jumlah kepadatan sel. Kepadatan sel semakin menurun dikarenakan nutrisi yang ada pada limbah tersebut sudah mulai berkurang seiring dengan waktu kultur dan laju kematian lebih ringgi dari laju pertumbuhan (fase kematian). Pola pertumbuhan sel Chlorella sp. selama proses pengolahan dapat dilihat pada Gambar 2.

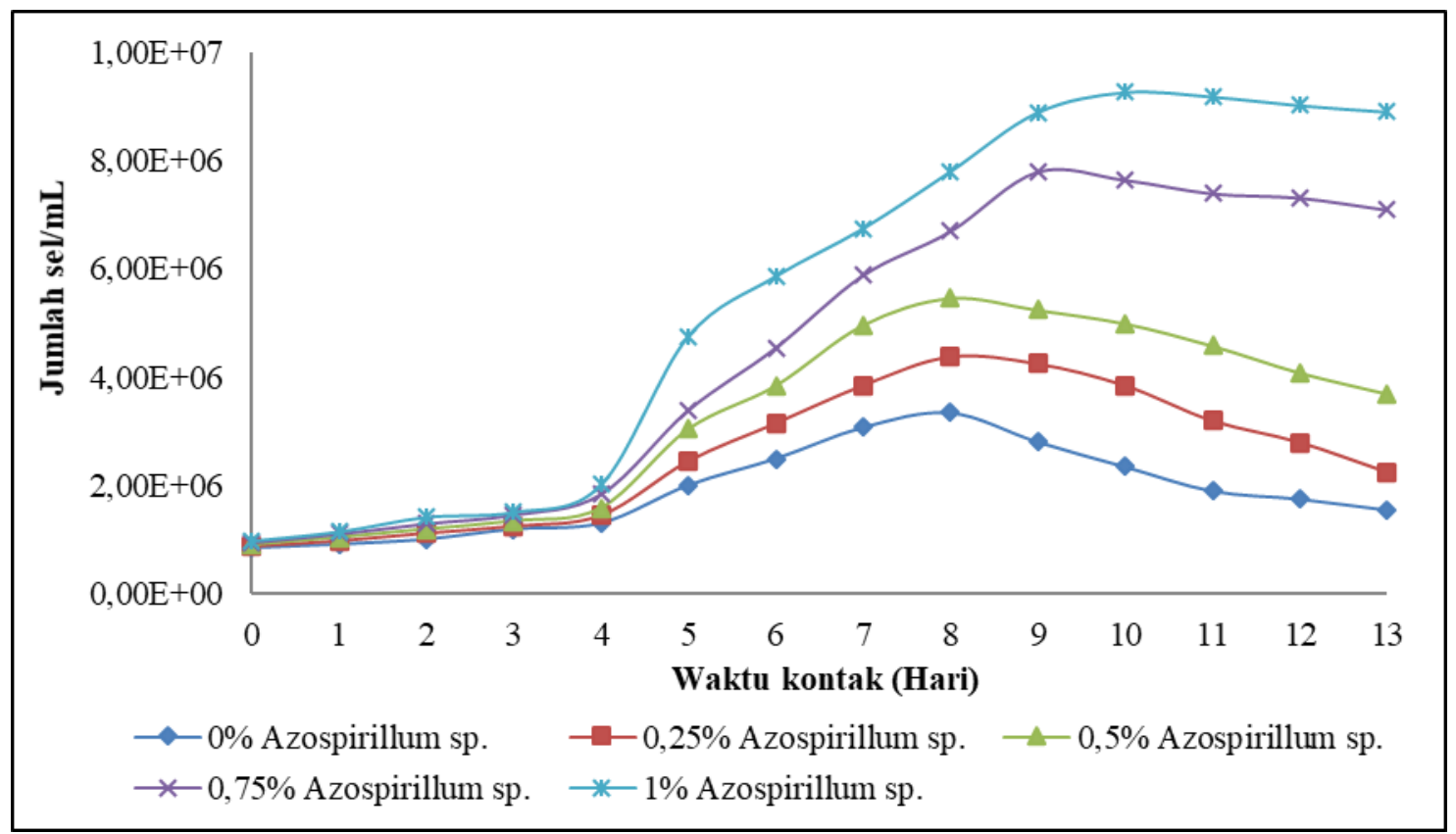

Gambar 2. Grafik Hubungan Variasi Konsentrasi Penambahan Bakteri Azospirillum sp.

Terhadap Jumlah Sel Mikroalga Chlorella sp.

(Hasil penelitian merupakan nilai rerata dengan $2 x$ pengulangan setiap perlakuan)

Berdasarkan Gambar 2 dapat diketahui bahwa perlakuan penambahan konsentrasi Azospirillum sp. memberikan pengaruh terhadap pertuham sel mikroalga. Penambahan Azospirillum sp. sebesar $1 \%$ menunjukkan jumlah sel mikroalga yang paling tinggi dari 
awal hingga akhir waktu kontak yaitu sebesar 9,26 x $10^{6} \mathrm{sel} / \mathrm{ml}$. Hal menunjukkan bahwa adanya penambahan bakteri Azospirillum sp. dengan konsentrasi yang lebih tinggi memberikan hasil yang lebih baik dibandingkan dengan perlakuan lainnya pada penelitian ini. Sesuai dengan pernyataan Nugroho et al (2016), bahwa semakin banyak bakteri yang ditambahkan pada kultivasi mikroalga, semakin tinggi pula pertumbuhan mikroalganya. Menurut Bashan et al (2004), ketika dua mikroorganisme (mikroalga dan bakteri) tumbuh bersama, ada interaksi biologis yang saling menguntungkan diantara keduanya. Studi menunjukkan bahwa oksigen dihasilkan dari proses fotosintesis mikroalga dapat dimanfaatkan oleh bakteri dan kemudian menghasilkan karbondioksida yang dimanfaatkan mikroalga untuk medukung pertumbuhan lebih lanjut.

Azospirillum sp. dikenal karena kemampuannya menghasilkan fitohormon yang disebut Indol Acetid Acid (IAA). Dalam kultivasi mikroalga, fitohormon ini dapat meningkatkan pertumbuhan, pembelahan sel, jumlah populasi mikroalga. Adanya penambahan fitohormon kedalam medium mikroalga dapat menghasilkan metabolisme dan produksi sel yang lebih banyak dibandingkan dengan tanpa penambahan fitohormon (Choix et al., 2014).

\subsection{Kadar Lipid Mikroalga Chlorella sp.}

Pada penelitian ini kandungan lipid yang didapatkan menunjukkan hasil yang berbeda pada masing-masing perlakuan. Hasil uji kadar lipid selama proses kultivasi menggunakan limbah cair tahu dapat dilihat pada Gambar 3 berikut.

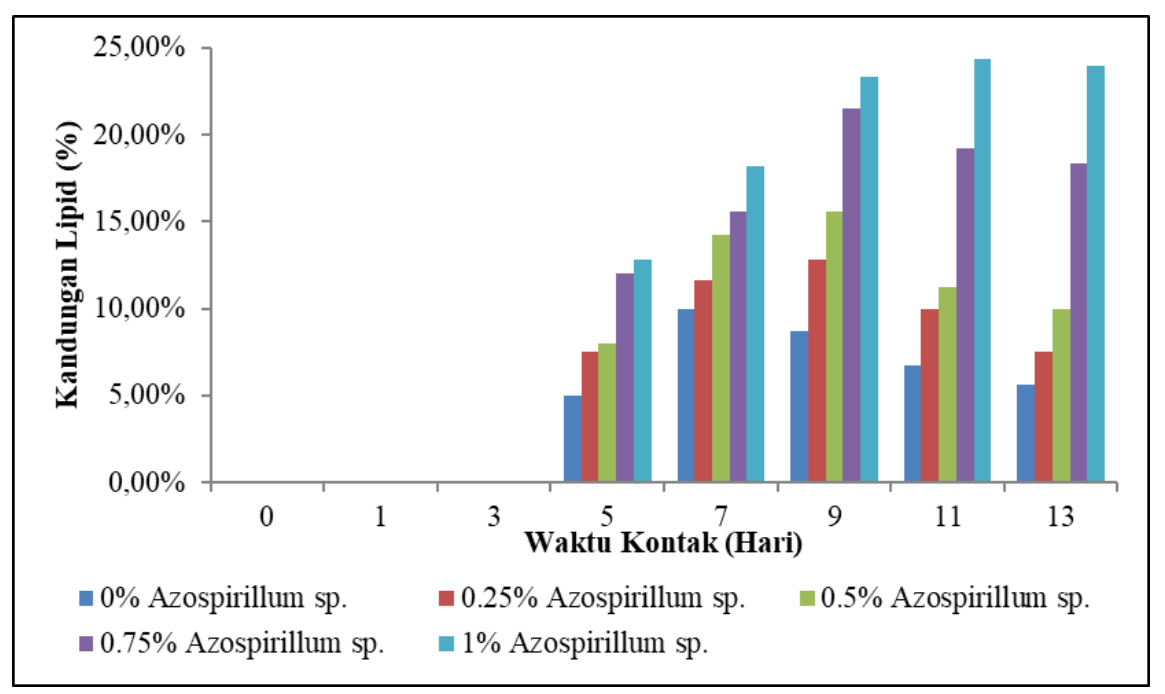

Gambar 3. Grafik Pengaruh Konsentrasi Bakteri Azospirillum sp. terhadap Kandungan Lipid Mikroalga Chlorella sp.

(Hasil penelitian merupakan nilai rerata dengan $2 x$ pengulangan setiap perlakuan) 
Gambar 3 menunjukkan bahwa konsentrasi penambahan bakteri Azospirillum sp. mempengaruhi kandungan lipid mikroalga. Dimana dalam penelitian ini, nilai kandungan lipid tertinggi dihasilkan oleh penambahan dosis bakteri Azospirillum sp. yang tertinggi pula. Pada penelitian ini, berdasarkan perlakuan penambahan $0 \% ; 0,25 \% ; 0,50 \% ; 0,75$; dan $1 \%$ bakteri, kandungan lipid tertinggi berada pada perlakuan penambahan bakteri Azospirillum sp. dengan konsentrasi $1 \%$ v/v yaitu sebesar 24,38\% pada waktu puncak hari ke-11 kultivasi. Hal ini sesuai dengan pernyataan Nurlaili et al (2015) bahwa semakin besar dosis bakteri yang ditambahkan maka semakin besar pula kandungan lipid pada mikroalga. Diketahuinya waktu puncak lipid ini dapat dijadikan dasar untuk waktu pemanenan mikroalga Chlorella sp.

Kandungan lipid pada mikroalga sepanjang proses kultivasi berbanding lurus dengan kerapatan sel serta biomassa mikroalga yang dihasilkan. Menurut Yang et al (2012), kandungan lipid yang tinggi disertai dengan produksi biomassa yang tinggi pula. Hal ini sesuai dengan pernyataan Hadiyanto (2010) bahwa biomassa mikroalga sejalan dengan pertumbuhan selnya, apabila pertumbuhan selnya meningkat maka biomassa dan lipid yang dihasilkan juga semakin tinggi dan jika pertumbuhan mikroalga menurun maka produktivitas lipid akan rendah. Menurut Allaf (2013), selain memproduksi $\mathrm{CO}_{2}$ yang dapat meningkatkan pertumbuhan mikroalga, fitohormon IAA yang dihasilkan bakteri berpengaruh positif terhadap kadar lipid mikroalga. Hal ini dikarenakan fitohormon memainkan peran unik dalam metabolisme dan fisiologi mikroalga, dimana fitohormon secara signifikan dapat meningkatkan jumlah sel yang dihasilkan selama pertumbuhan dan pembelahan sel sehingga menaikkan jumlah biomassa dalam produksi lipid mikroalga (Bahsan et al., 2002).

\subsection{Penyisihan Nitrogen Total pada Limbah Cair Tahu}

Pada penelitian ini, efisiensi penyisihan nitrogen total tertinggi diperoleh pada akhir kultivasi yaitu hari ke-13. Penurunan konsentrasi nitrogen total terjadi seiring lamanya waktu kontak. Bashan (2004) mengatakan bahwa seiring dengan lamanya waktu kontak sel alga dengan air limbah semakin tinggi pula penyisihan nitrogen yang terjadi. Dari konsentrasi yang didapat maka dapat diketahui efisiensi penyisihan. Berdasarkan perlakuan penambahan $0 \% ; 0,25 \%$; $0,50 \%$; 0,75 ; dan $1 \%$ bakteri, didapatkan nilai efisiensi terbaik pada perlakuan penambahan bakteri Azospirillum sp. 1\% v/v yaitu 66,67\%. Pada penelitian ini, perlakuan penambahan bakteri Azospirillum sp. dalam kultivasi Chlorella sp. memiliki efisiensi yang tinggi dibandingkan dengan tanpa penambahan bakteri (0\% Azospirillum 
sp.) dikarenakan adanya hubungan timbal balik antara bakteri dan mikroalga. Menurut Susanti et al (2013), adanya perlakuan penambahan bakteri Azospirillum sp. berpengaruh terhadap kandungan kualitas air di dalam media kultur. Grafik nilai konsentrasi nitrogen dan efisiensi penyisihan nitrogen total untuk setiap perlakuan dapat dilihat pada Gambar 4.

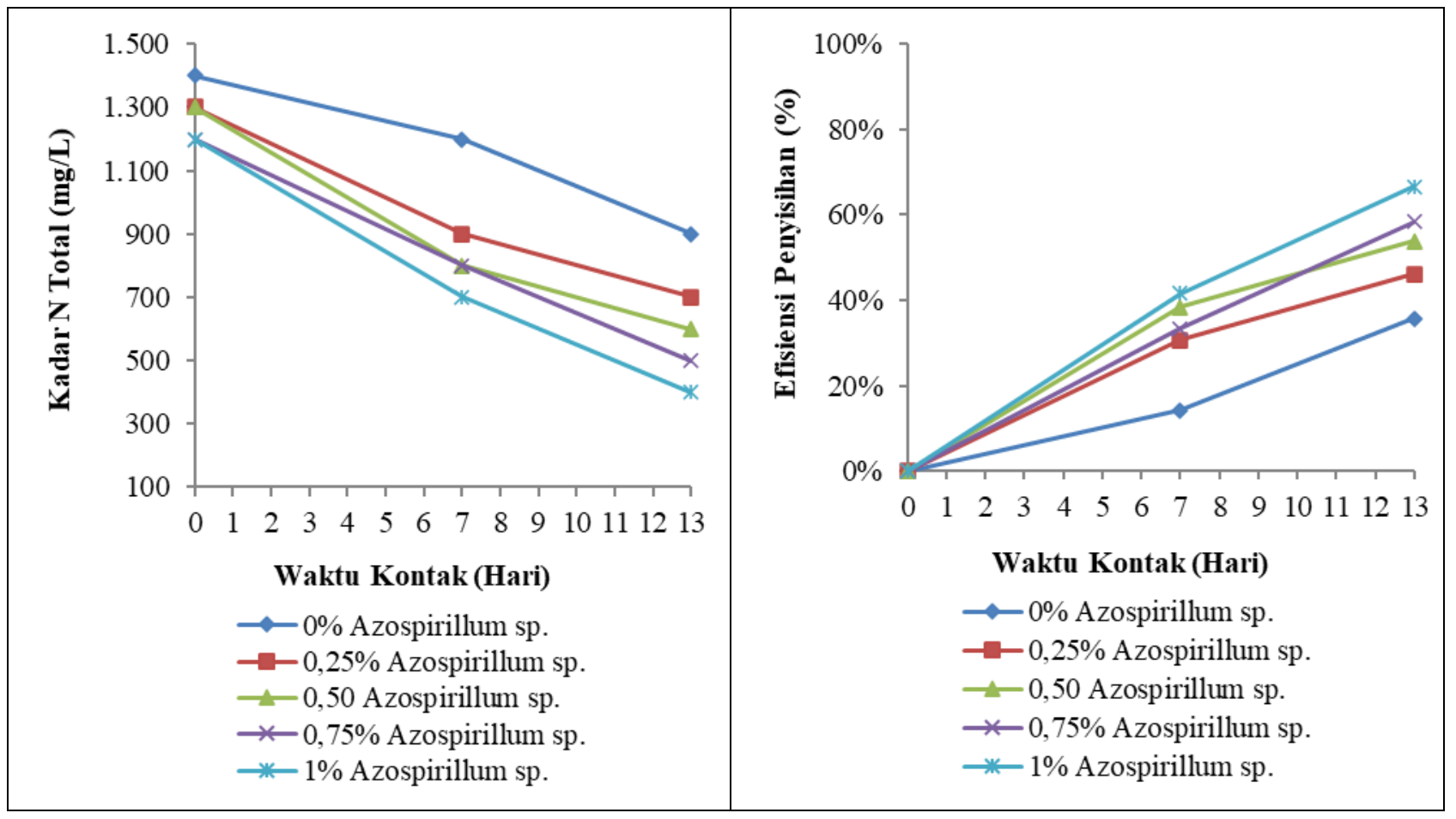

(a)

(b)

Gambar 4. (a) Grafik Nilai Konsentrasi Nitrogen Total dan (b) Efisiensi Penyisihan Nitrogen Total

(Hasil penelitian merupakan nilai rerata dengan $2 x$ pengulangan setiap perlakuan)

Choix et al (2014), mengatakan bahwa dalam pengolahan air limbah, Azospirillum sp. dapat meningkatkan aktivitas enzim glutamin sintetase (GS) yang terlibat dalam proses metabolisme nitrogen dan penyerapan amonium oleh mikroalga. Asimilasi amonium merupakan proses biokimia penting untuk pertumbuhan dan perkembangan mikroalga (Lu et al., 2005). Menurut Borowitzka dan Moheimani (2013), jalur penting untuk asimilasi nitrogen adalah melalui sistem enzim glutamin sintetase, dimana glutamat bereaksi dengan amonium (dengan bantuan ATP) membentuk asam amino glutamin.

Studi sebelumnya menunjukkan bahwa fitohormon yang dihasilkan bakteri Azospirillum sp. berpengaruh pada kinerja enzim glutamin sintetase mikroalga. Gonzales dan Bashan (2000) mengatakan ada indikasi bahwa fitohormon IAA terlibat dalam mendorong pertumbuhan mikroalga yang dikaitkan dengan peningkatan aktivitas glutamin sintetase yang lebih besar. Pada kultur media dengan penambahan konsentrasi bakteri Azospirillum 
sp., mikroalga Chlorella sp. dapat menyerap lebih banyak nitrogen dibandingkan tanpa penambahan bakteri. Nitrogen dibutuhkan mikroalga untuk menyintesis protein, pertumbuhan, dan pembentukan sel.

Penurunan konsentrasi nitrogen pada limbah disebabkan adanya asimilasi atau penyerapan nitrogen terlarut. Maharsyah (2013) mengatakan bahwa bentuk senyawa nitrogen yang disukai oleh mikroalga adalah amonium $\left(\mathrm{NH}_{4}{ }^{+}\right)$, karena proses transportasi dan asimilasi ion ammonium oleh mikroalga membutuhkan energi yang lebih sedikit dibandingkan dengan transportasi asimilasi ion nitrat $\left(\mathrm{NO}_{3}^{-}\right)$. Senyawa $\mathrm{N}$ dalam bentuk $\mathrm{NH}_{4}{ }^{+}$ini kemudian diasimilasi bersama-sama dengan asam glutamat menjadi berbagai jenis makromolekul organik yang dibutuhkan oleh sel Chlorella sp. Sedangkan dalam bentuk nitrat, nutrient harus dikonversikan terlebih dahulu menjadi amonium. Nitrat akan direduksi oleh nitrit reduktase menjadi nitrit kemudian direduksi menjadi amonium (Fakhri, 2020). Karena asimilasi amonium tidak memerlukan reaksi redoks, maka ia mengkonsumsi lebih sedikit energi dari pada asimilasi nitrat (Meirinawati, 2017).

\section{KESIMPULAN}

Penambahan bakteri Azospirillum sp. pada kultivasi Chlorella sp. di medium limbah cair tahu dapat mempengaruhi jumlah sel mikroalga. Jumlah sel tertinggi sebesar 9,26 x $10^{6}$ $\mathrm{sel} / \mathrm{ml}$ didapatkan pada perlakuan penambahan bakteri Azospirillum sp. $1 \%$ (v/v). Penambahan bakteri Azospirillum sp. mempengaruhi kandungan lipid mikroalga, semakin besar dosis bakteri yang ditambahkan pada penelitian ini maka semakin besar pula kandungan lipid pada mikroalga. Kadar lipid tertinggi sebesar 24,38\% diperoleh pada perlakuan penambahan bakteri Azospirillum sp. $1 \%$ (v/v) didapatkan pada waktu puncak hari ke 11. Pengaruh penambahan konsentrasi bakteri Azospirillum sp. terhadap efisiensi penyisihan $\mathrm{N}$ total pada penelitian ini yaitu semakin besar konsentrasi bakteri Azospirillum sp. yang ditambahkan dalam medium limbah cair tahu maka efisiensi penyisihan semakin meningkat sehingga nilai $\mathrm{N}$ total semakin kecil. Efisiensi penyisihan $\mathrm{N}$ total tertinggi terjadi pada penambahan bakteri Azospirillum sp. $1 \%$ (v/v) sebesar 66,67\%.

\section{DAFTAR PUSTAKA}

Adi, M. (2015). Fiksasi Emisi Karbon Dioksida dengan Kultivasi Mikroalga Menggunakan Nutrisi dari Air Limbah Industri Susu. Jurnal Riset Industri, 9(1) : 13-21.

Allaf, M.M. (2013). Effect of Plant Hormones on the Production of Biomass and Lipid in Microalgae. Tesis. The University of Western Ontario. 
Arwiyanto, T., M. Goto., and Y. Takikawa. (1993). Characterization of Bacteriocins Produced by Pseudomonas solanacearum. Journal Annals Phytopathological Society of Japan, 59: 114-122.

Bashan. L. E., Antoun, H., and Bashan, Y. (2008). Involvement of Indole-3-Acetic-Acid Produced By The Growth-Promoting Bacterium Azospirillum spp. In Promoting Growth Of Chlorella vulgaris. J. Phycol, 44(4):938-947.

Bashan, L. E., Hernandez, J. P., Morey, T., and Bashan, Y. (2004). Microalgae GrowthPromoting Bacteria as "Helpers" for Microalgae: a Novel Approach for Removing Ammonium and Phosphorus from Municipal Wastewater. Water Res. ,38 (2):466-474.

Bashan, L. E., Bashan,Y., Moreno,M., Lebsky,V.K., and Bustillos, J.J. (2002). Increased pigment and lipid content, lipid variety, and cell and population size of the microalgae Chlorella spp. when co-immobilized in alginate beads with the microalgae-growth-promoting bacterium Azospirillum brasilense. Can. J. Microbiol, 48 (6): 514-521.

Borowitzka, M.A. and Moheimani, N.R. (2013). Algae for Biofuel and Energy. New York: Springer.

Choix, Francisco J., Yoav B., Alberto M., and Luz E. de-Bashan. (2014). Enhanced Activity of ADP Glucose Pyrophosphorylase and Formationof Starch Induced by Azospirillum brasilense in Chlorella vulgaris. Journal of Biotechnology. 177 (10) :22-34.

Christenson, L and Sims, R. (2011). Production and Harvesting of Microalgae for Wastewater Treatment, Biofuels, and Bioproducts. Journal Biotechnol. Adv, 29 (6):686-702.

Dahril, T. (2012). Rotifer, Biologi dan Pemanfaatannya. Pekanbaru: Unri Press.

Fakhri, M., Antika, P.W., Ekawati, A.W., dan Arifin, B.A. (2020). Pertumbuhan, Kandungan Pigmen, dan Protein Spirulina platensis yang Dikultur pada $\mathrm{Ca}\left(\mathrm{NO}_{3}\right)_{2}$ Dengan Dosis yang Berbeda. Journal of Aquaculture and Fish Health. $91(: 43-44$.

Fithriani, D., dan Melanie, S. (2015). Rendemen Minyak dari Mikroalga Spirulina sp. dan Chlorella sp. dengan Teknik Pemecahan Dinding Sel. Jurnal Riset, 1(1):

Gonzalez, L. E., and Bashan, Y. (2000). Increased Growth of The Microalga Chlorella vulgaris when Co-Immobilized and Cocultured in Alginate Beads with The Plant Growth Promoting Bacterium Azospirillum brasilense. Appl. Environ. Microbiol, 
66(4):27-31.

Hadiyanto. (2010). Produksi Mikroalga Berbiomassa Tinggi dalam Bioreaktor Open Pond. Jurnal Prosiding Seminar Nasional Teknik Kimia, A02:1-6.

Hadiyanto dan Azim, M. (2012). Mikroalga Sumber Pangan dan Energi Masa Depan. Semarang: UPT UNDIP.

Hadiyanto dan Hidayat. (2014). Biofiksasi $\mathrm{CO}_{2}$ oleh Mikroalga Chlamydomonas sp. dalam Photobioreaktor Tubular. Jurnal Jurusan Teknik Kimia, 15 (1): 37-42.

Harianja, D. C. N., Sri Rezeki M., dan Chairul. (2019). Kultivasi Mikroalga Chlorella sp. secara Fed-Batch Dalam Media POME Sebagai Bahan Baku Bioetanol. JOM FTEKNIK, 6(2): 1-5.

Lu, B., Yuan, Y., Zhang, C., Ou, J., Zhou, W., and Lin, Q. (2005). Modulation of Key Enzymes Involved in Ammonium Assimilation and Carbon Metabolism by Low Temperature in Rice (Oryza sativa L.) Roots. Plant Sci, 169 (2):295-302.

Maharsyah, Taif. (2013). Efektifitas Penambahan Plant Growth Promoting Bacteria (Azospirillum sp.) dalam Meningkatkan Pertumbuhan Mikroalga (Chlorella sp.) pada Media Limbah Cair Tahu Setelah Proses Anaerob. Skripsi. Universitas Brawijaya.

Meirinawati, H. (2017). Transformasi Nitrogen di Laut. Jurnal Oseana, 42(1): 36-46.

Nugroho, W. A., Lutfi, M., and Susilo. (2016). Promoting the Growth of Chlorella vulgaris in Secondary Wastewater Treatment Effluent of Tofu Industry using Azospirillum sp. International Journal on Advanced Science Engineering Informationn Technology, 6 (3): 1-6.

Nurlaili, F.R, Hendrawan, Y., dan Nugroho, W.A. (2015). Pengaruh Dosis Pertambahan Bakteri (Azospirillum sp.) Terhadap Kelimpahan Populasi Mikroalga (Chlorella sp.) pada Media Kultur Limbah Cair Biogas (Setelah Proses Anaerob). Jurnal Keteknikan Pertanian Tropis dan Biosistem, 3 (2): 121-126.

Nursoid. (2008). Kemampuan Azospirillum sp. JG3 dalam Menghasilkan Lipase pada Medium Campuran Dedak dan Onggok dengan Waktu Inkubasi Berbeda. Purwokerto: Fakultas Biologi Universitas Jenderal Soedirman.

Putri, E.V. (2012). Cultivation of Microalgae Using Palm Oil Mill Effluent for Lipid Production. Thesis. Faculty of Civil Engineering, Universiti Teknologi Malaysia. Spaepen, S., Vanderleyden, J., and Remans, R. (2007). Indole Acetic Acid In Microbial and Microorganism-Plant Signaling. FEMS Microbiol, 31(4):425-448.

Susanti, T. I., Musthofa. L., dan Wahyunanto. A. N. (2013). Pengaruh Penambahan Plant- 
Growth Promoting Bacteria (Azospirillum sp.) terhadap Laju Pertumbuhan Mikroalga (Chlorella sp.) pada Media Limbah Cair Tahu Sintetis. Jurnal Keteknikan Pertanian Tropis dan Biosistem, 1 (3): 239-248.

Tang, YZ, Koch, F. dan Gobler, CJ. (2010). Most Harmful Algal Bloom Species are Vitmin B1 and B12 Auxotrophs. Journal PNAS ,107 (20) : 756 - 761.

Wijoseno, Tangguh. (2011). Uji pengaruh variasi media kultur terhadap tingkat pertumbuan dan kandungan protein, lipid, klorofil, dan karatenoid pada mikroalga Chlorella vulgaris Buitenzorg. Skripsi. Fakultas Teknik Universitas Indonesia.

Yang, X., Liu, P., Hao, Z., Shi, J., Zhang, S. (2012). Characterization and identification of freshwater microalgal strains toward biofuel production. BioResources. 7(1):686-695.

Yao, S., Lyu, S., An, Y., Lu, J., Gjermansen. C., and Schramm, A. (2018). MikroalgaeBacteria Symbiosis in Microalgal Growth and Biofuel Production: A Review. Journal of Applied Microbiology 126(2) : 359-368

Zulfarina, Sayuti, I and Putri, H. (2013). Potential Utilization of Algae Chlorella Pyrenoidosa for Rubber Waste Management. Prosiding Semirata FMIPA Universitas Lampung, 1 (1) : 511 - 520 